\title{
HILAH DALAM JUAL BELI SALAM
}

\author{
Muhammad Syahrullah \\ Universitas Muhammadiyah Riau \\ m.syahrullah@umri.ac.id
}

\begin{abstract}
ABSTRAK
Penelitian ini mengkaji hilah dalam jual beli Salam. Hilah dipandang sebagai menghindarkan diri dari kewajiban syara' yang lebih penting dari pada amaliah yang dilakukan. Penelitian ini menyimpulkan bahwa Hilah merupakan bentuk dari respon hukum Islam terhadap perkembangan kepentingan masyarakat, dalam menarik kemaslahatan yang dibutuhkan, dalam pemenuhan yang bersifat dharuri. Metodologi penelitian ini menggunakan pendekatan hukum normativ dengan menggunakan ushul fikih, kaedah fikih, dan perbandingan pendapat fikih untuk menentukan pendapat yang arjah dan ashlah. Hasil dari penelitian ini diharapkan adanya pemahaman bahwa Hilah merupakan tindakan reaktif yaitu upaya mencari legitimasi hukum untuk melakukan hukum yang lebih ringan dengan pertimbangan maslahat, yang dilakukan untuk menyelesaikan (merespon) problematika masyarakat (menghindari dari perbuatan yang dilarang).
\end{abstract}

Kata Kunci: Hilah, Jual Beli, Salam

\section{PENDAHULUAN}

Secara etimologi Hilah berarti kecerdikan, tipu daya, muslihat, siasat dan alasan yang dicari-cari untuk melepaskan diri dari suatu beban/tanggung jawab (Aziz Dahlan, 1977:553). Menurut as-Syatibi Hilah dipandang sebagai upaya melakukan suatu amalan yang pada lahirnya dibolehkan, untuk membatalkan hukum syara' lainnya, sekalipun hilah pada dasarnya adalah mengerjakan suatu pekerjaan yang dibolehkan, namun terkadang maksud pelaku adalah untuk menghindarkan diri dari kewajiban syara' yang lebih penting dari pada amaliah yang dilakukan (Abu Ishaq Al-Syatibi, 1999:201). Sedangkan al-Khadduri mengartikan Hilah sebagi suatu konsep legal, yang secara sadar digunakan sebagai sarana untuk mencapai tujuan agar supaya tidak illegal, berguna bagi suatu tujuan fiksi legal yang bijak, yang sebenarnya berarti subordinasi keadilan substantive pada keadilan procedural. Hilah merupakan jalan keluar menurut cara-cara hukum (Majid Al-Khudduri, 1995:225).

Term Hilah dapat dinilai sebagai jalan keluar, disamping itu juga, term ini sering dijadikan alasan untuk menghindar dari pembebanan hukum, karena hilah muncul sebagai reaksi dari nilai-nilai kemaslahatan yang oleh masyarakat dipandang penting, sedangkan nilai hukum dianggap belum menyentuh kebutuhan, yang oleh sebahagian masyarakat dianggap sebagai kebutuhan yang bersifat dharuri. 
As-salam dalam istilah fikih disebut juga as-salaf. Secara etimologis, kedua kata memiliki makna yang sama, yaitu mendahulukan pembayaran dan mengakhirkan barang. Penggunaan kata as-salam biasanya digunakan oleh orangorang Hijaz, sedangkan penggunaan kata as-salaf biasanya digunakan oleh orangorang Irak. Dalam penelitian ini akan dibahas dasar hukum jual beli salam, rukun dan syarat salam, dan contoh-contoh hilah dalam transaksi salam.

Secara terminologis, salam adalah menjual suatu barang yang penyerahannya ditunda, atau menjual suatu barang yang ciri-cirinya disebutkan dengan jelas dengan pembayaran modal terlebih dahulu, sedangkan barangnya diserahkan dikemudian hari (M. Ali Hasan, 2003:143). Menurut Sayyid Sabiq, assalam atau as-salaf (pendahuluan) adalah penjualan sesuatu dengan kriteria tertentu (yang masih berada) dalam tanggungan dengan pembayaran segera atau disegerakan (Sayyid Sabiq. 1988:110). Menurut Kompilasi Hukum Ekonomi Syariah, salam adalah jasa pembiayaan yang berkaitan dengan jual beli yang pembiayaannya dilakukan bersamaan dengan pemesanan barang (KHES, 2008:34).

Selain definisi tersebut, terdapat beberapa definisi lain mengenai salam yang berkembang di kalangan fuqaha, seperti Fuqaha Syafi'iyah dan Hanbali mendefinisikan jual beli salam adalah: "Akad yang disepakati dengan menentukan ciri-ciri tertentu dengan membayar harganya lebih dahulu, sedangkan barangnya diserahkan kemudian dalam suatu majlis akad." Sedangkan Fuqaha Malikiyah mendefinisikan jual beli salam sebagai "Jual beli yang modalnya dibayar dahulu, sedangkan barangnya diserahkan sesuai dengan waktu yang disepakati" (Wahbah al-Zuhaili, 2008:359).

Dari beberapa definisi di atas, disimpulkan bahwa yang dimaksud jual beli salam adalah transaksi jual beli yang pembayarannya dilaksanakan ketika akad berlangsung dan penyerahan barang dilaksanakan di akhir sesuai dengan perjanjian yang telah disepakati oleh penjual dan pembeli.

Dalam menggunakan akad salam, hendaknya menyebutkan sifat-sifat dari objek jual beli salam yang mungkin bisa dijangkau oleh pembeli, baik berupa barang yang bisa ditakar, ditimbang maupun diukur. Disebutkan juga jenisnya dan semua identitas yang melekat pada barang yang dipertukarkan yang menyangkut kualitas barang tersebut. Jual beli salam juga dapat berlaku untuk mengimport barangbarang dari luar negeri dengan menyebutkan sifat-sifatnya, kualitas dan kuantitasnya. Penyerahan uang muka dan penyerahan barangnya dapat dibicarakan bersama dan biasanya dibuat dalam suatu perjanjian (M. Ali Hasan, 2003: 144). Dalam dunia bisnis modern, bentuk jual beli salam dikenal dengan pembelian dengan cara pesan (Musthafa Kamal, 2003:356). Tujuan utama dari jual beli pesanan adalah untuk saling membantu dan menguntungkan antara konsumen dengan produsen.

\section{METODOLOGI}

Pendekatan penelitian ini adalah hukum normative yakni penelitian yang dilakukan untuk mengkaji penerapan kaidah-kaidah atau norma-norma dalam 
Hukum Islam baik pada tataran metodologis ataupun fikih (Jhonny Ibrahim, 2006:321). Pembahasan dari penelitian hukum normative meliputi penelitian terhadap asas-asas hukum, penelitian terhadap sistematika hukum, penelitian terhadap taraf sinkronisasi hukum, penelitian sejarah hukum, dan penelitian perbandingan hukum.

Pokok permasalahan dalam penelitian ini berada dalam ruang lingkup kajian Hukum Islam dan pendekatan yang dipergunakan adalah pendekatan ilmu usul fikih. Di dalam kajian usul fikih, khususnya dalam memahami tujuan penetapan hukum-hukum syara' menggunakan dua bentuk pendekatan yang saling berkaitan, yaitu: pendekatan kaidah kebahasaan dan pendekatan kaidah makna (Maqâshid alSyari'ah). Kedua bentuk pendekatan tersebut digunakan untuk memahami berbagai istilah yang dikemukakan oleh para Ulama di dalam pengembangan konsep-konsep pemikiran fikihnya, karena konsepnya digali dan bersumber dari nash-nash Al Quran dan Sunnah, yang keduanya dalam bahasa Arab.

Penggunaan pendekatan kaidah kebahasaan adalah sangat relevan, karena melalui pendekatan ini dapat ditemukan penjelasan dan keterangan serta ketentuan-ketentuan yang dapat digunakan untuk memahami teks Syari'at secara benar, sesuai dengan pemahaman-pemahaman orang-orang Arab tentang teks-teks nash yang diturunkan. Sedangkan pendekatan kaidah makna dipergunakan untuk menganalisa metode ijtihad para Ulama, dalil-dalil yang digunakannya serta kesimpulan yang dirumuskannya terhadap berbagai masalah dalam akad.

\section{HASIL PENELITIAN}

Jual beli salam ini diperbolehkan dalam Islam berdasarkan dalil al-Qur'an, alHadits, dan Ijma' (kesepakatan ulama'), yaitu diantaranya Firman Allah yang menjelaskan tentang diperbolehkannya jual beli salam terdapat dalam surat alBaqarah ayat 282: "Hai orang-orang yang beriman, apabila kamu bermu'amalah tidak secara tunai untuk waktu yang ditentukan, hendaklah kamu menuliskannya. dan hendaklah seorang penulis di antara kamu menuliskannya dengan benar.

Hadits Nabi yang menerangkan tentang hukum jual beli salam, yaitu ketika Rasulullah SAW datang ke Madinah, dan pada saat itu orang banyak sedang mengadakan salam pada tamar untuk jangka waktu dua dan tiga tahun. Maka Rasulullah SAW bersabda: "Barangsiapa menghutangkan, hendaklah ia menghutangkan dalam harga yang diketahui dan timbangan yang diketahui, hingga masa yang diketahui." (Shahih Bukhari, 1992:61)

Sabda Rasulullah SAW ini muncul ketika beliau pertama kali hijrah ke Madinah, dan mendapati para penduduk Madinah melakukan transaksi jual beli salam. Jadi Rasulullah SAW membolehkan jual beli salam asal akad yang dipergunakan jelas, ciri-ciri barang yang dipesan jelas, dan ditentukan waktunya.

Ibnu Abbas r.a., berkata: "Aku bersaksi bahwa as-salaf yang dijamin untuk waktu tertentu benar-benar dihalalkan Allah di dalam kitabullah dan diizinkan." Kemudian ia membaca ayat Allah: "Hai orangorang yang beriman, apabila kamu 
bermu'amalah tidak secara tunai untuk waktu yang ditentukan, hendaknya kamu menuliskannya dengan benar."(Sunan Abu Dawud, Hadis 3463)

Berdasarkan kedua hadits tersebut, jual beli salam ini hukumnya dibolehkan, selama ada kejelasan ukuran, timbangan, dan waktunya yang ditentukan. Dasar hukum jual beli ini telah sesuai dengan tuntutan syariat dan kaidah-kaidahnya. Bahkan dalam prakteknya, jual beli salam juga tidak menyalahi qiyas yang membolehkan penangguhan penyerahan barang seperti halnya dibolehkannya penangguhan dalam pembayaran. (Burhanuddi S, 2009:213)

Ibnu Mundzir dan lainnya meriwayatkan adanya ijma' ulama' atas kebolehan transaksi jual beli salam. Kebutuhan manusia untuk bertransaksi itulah yang mendorong diperbolehkannya jual beli salam. Karena satu pihak yang bertransaksi ingin mendapatkan pembayaran yang dipercepat, sementara pihak yang lain ingin mendapatkan barang yang jelas atau pasti. (Saleh Al-Fauzan, 2005:407)

Transaksi salam juga memberikan kemudahan kepada manusia yang berkepentingan terhadap bentuk transaksi jual beli salam ini. Selain itu, transaksi salam juga merupakan dispensasi bagi manusia yang di dalamnya juga terdapat unsur yang sejalan dengan upaya merealisasikan kemaslahatan perekonomian.

Ulama Hanafiyah menyatakan bahwa rukun jual beli salam ini hanya ijab (ungkapan dari pihak pemesan dalam memesan barang) dan qabul (ungkapan pihak produsen untuk mengerjakan barang pesanan). Lafaz yang dipakai dalam jual beli pesanan (indent) menurut ulama Malikiyah, Hanafiyah, dan Hanabilah adalah lafaz as-salam, as-salaf, atau al-bay' (jual beli). Sedangkan menurut ulama Syafi'iyah, lafaz| yang boleh dipergunakan dalam jual beli pesanan ini hanya as-salam dan assalaf. Alasan ulama Syafi'iyah adalah bahwa menurut kaidah umum (analogi) jual beli seperti ini tidak dibolehkan, karena barang yang dibeli belum kelihatan ketika akad. Akan tetapi, syara' membolehkan jual beli ini dengan mempergunakan lafaz as-salam dan as-salaf. Oleh sebab itu, perlu pembatasan dalam pemakaian kata itu sesuai dengan pemakaian syara'.

Adapun rukun jual beli salam menurut jumhur ulama, selain Hanafiyah, terdiri atas Al-Aqidain, Objek jual beli salam, dan Sigat (Ijab dan Qabul). Al-Aqid adalah orang yang melakukan akad. Dalam perjanjian salam, pihak penjual disebut dengan al-Muslam Ilaih (orang yang diserahi) dan pihak pembeli disebut al-Muslam atau pemilik as-salam (yang menyerahkan). Keberadaan aqid sangatlah penting, sebab tidak dapat dikatakan akad jika tidak ada aqid, begitu pula tidak akan terjadi Ijab dan qabul tanpa adanya aqid (Chairuman dkk, 1994:48).

Objek jual beli salam adalah harga dan barang yang dipesan. Barang yang dijadikan sebagai objek jual beli disebut dengan al-Muslam Fih. Barang yang dipesan harus jelas ciri-cirinya dan waktu penyerahannya. Harga (ra'su malis salam) dalam jual beli salam harus jelas serta diserahkan waktu akad.

Ijab (pernyataan melakukan ikatan) dan qabul (pernyataan penerimaan ikatan) sesuai dengan kehendak syari'at yang berpengaruh pada objek perikatan. Yang dimaksud dengan "sesuai dengan kehendak syari'at" adalah bahwa seluruh 
perikatan yang dilakukan oleh dua pihak atau lebih tidak boleh, apabila tidak sejalan dengan kehendak syara'.

Ulama' Malikiyah dan Hanafiyah mensyaratkan aqid harus berakal, yakni sudah mumayyiz, anak yang agak besar yang pembicaraan dan jawaban yang dilontarkannya dapat dipahami, serta berumur minimal 7 tahun. Oleh karena itu, anak kecil, orang gila dan orang bodoh tidak boleh menjual harta sekalipun miliknya (Hendi Suhendi, 2010:74).

Banyak Sekali contoh-contoh Hilah dalam Jual Beli Salam, dan berikut akan dipaparkan diantaranya. Pertama, Apabila telah didatangkan barang yang di pesan pada waktu yang disepakati, apabila pemiliknya menolak menerimanya maka boleh dipaksa menerimanya, atau apabila datang sebelum waktu yang disepakati tetapi seperti akan menolaknya, dan penolakan ini akan membahayakan seperti hewan yang butuh makanan, buah atau daging yang harus segera dimakan, atau barang yang perlu tempat aman seperti gandum dan sebagainya, maka boleh dipaksakan untuk diterima.

Hal ini dikiaskan kepada seseorang yang memiliki hutang tidak boleh didesak pembayarannya, apabila yang berhutang membayarnya pada waktu yang berbahaya menerimanya maka harus diterima. Contohnya adalah apabila telah didatangkan barang pesanan maka tanpa keraguan wajib diterima, dan menundanya akan membahayakan, dan tidak boleh bagi yang memiliki barang tersebut untuk membahayakannya.

Kedua, seseorang yang memiliki hak diminta oleh muslam ilaih untuk tidak memenuhi atau melepaskan dari kewajiban dari menunaikannya, tidaklah wajib bagi orang tersebut untuk menerimanya. Contohnya adalah seperti orang yang akan diqishos, kalau dibolehkan maka ia akan meminta untuk selalu ditunda, dan ini akan menyebabkan akan gagalnya qishos, seperti ini disebutkan oleh Imam Haramain dalam bab Perampokan, dan Ar-Rafi'I dalam bab Pelaksanaan Qishos.

Ketiga, seorang yang memiliki piutang meminta kepada yang berhutang untuk menunaikannya pada waktu yang ditentukan, maka yang lebih sah untuk menentukan adalah yang memiliki piutang. Contohnya adalah di dalam Qard, seorang yang berhutang ingin menahan hutang qard tersebut, sedangkan yang berpiutang menginginkan agar qard tersebut ditunaikan, maka yang lebih sah adalah keinginan yang berpiutang. Contoh kedua adalah barang temuan yang dimiliki oleh penemu kemudian muncul pemiliknya, maka yang benar dikembalikan kepadanya, dan pergantiannya telah ditetapkan dengan kepemilikan. Telah disebutkan bahwa kepemilikan dalam barang temuan sama dengan kepemilikan dalam Qard

Keempat, seseorang yang dalam tanggungannya memiliki kemampuan dalam menunaikan kewajiban atasnya, maka dengannya diperbolehkan mengganti dengan sejenis. Sebagai contoh dalam barang temuan apabila dimiliki oleh penemu, dan hilang darinya, kemudian muncul pemiliknya, dan yang menemukan ingin memberikan penggantinya, dan pemilik menginginkan jumlah yang sesuai, maka yang berhak menentukan adalah penemu lebih shoheh. 
Kelima, harta yang ditetapkan dengan akad Mu'awadhoh (karung), yang tidak jelas jenis, takaran dan sifatnya. Contohnya seperti kewajiban pokok bagi seorang istri, apakah hanya sekedar memasak, atau lainnya, dan memasak pun berbeda-beda bentuk sifat, dan batasannya. Dan contoh lainnya adalah pakaian pada setiap daerah berbeda, ukuran yang pantas terhadapnya tidak jelas panjang, lebar dan ketatnya, dan apalagi ketika wanita menampakkan kepada calon laki-laki batasan yang diperbolehkan.

Keenam, seseorang menentukan tempat ditunaikannya pesanan, dan dengannya wajib menerimanya di lainnya. Contohnya apabila tempat yang ditentukan telah rusak, maka menurut ar-Rafi'I dapat dalam tiga bentuk tampa mentarjihnya: pertama, wajib menerimanya di tempat tersebut; kedua tidak wajib, dan yang menerima boleh memilih; ketiga, dia diqiaskan pada pertumbuhan jiwa, bahwa dia ditentukan tempat yang dekat lebih baik.

Ketujuh, harta yang dimiliki seorang tuan yang bebas tidak boleh digantikan sebagai hutang atau lainnya. Contohnya dalam zakat apabila dilarang dalam memindahkannya dari negri diambilnya harta tersebut, dan dibatasi yang berhak, maka sesungguhnya ia memilikinya secara bebas dan dapat diwariskan, dan oleh karenanya tidak boleh diambil gantinya sama saja apakah tetap jumlahnya atau pindah kepada ahli waris, karena kepemilikan seseorang terhadap harta tersebut berbeda dengan kepemilikan orang lain atasnya. Begitulah yang dikatan Ar-Rafi'I dalam Kitab Kitabah.

\section{DISKUSI}

Diantara pendapat ada yang menyebutkan bahwa hilah sebagai mencari celah-celah untuk merekayasa, membuat-buat trik atau tipu daya hal-hal yang telah jelas haram dengan upaya menyamarkan keadaan, sehingga akan tampak menjadi halal atau boleh. Berbagai cara dilakukan untuk mengelabui kebanyakan orang, atau untuk memperdaya orang-orang yang kurang wara' dalam agamanya, sehingga mendapatkan label halal atau label boleh dalam bermuamalah atau jual beli. Bahkan menyebutkan bahwa sekedar memutar cara atau jalan untuk melampiaskan keserakahan hawa nafsu, agar bisa menikmati yang haram maupun yang subhat.

Pemahaman terhadap terminology hilah menjadi sangat penting sehingga hilah tidak dianggap sebagai menghalalkan yang haram. Perlu adanya standar dan ketentuan yang baku dalam penerapan hilah. Disamping itu, pendekatan makna (maqashid Syariah) harus mengambil peran yang lebih besar, sehingga hukum baru yang ditetapkan tersebut dapat mendatangkan maslahah atau manfaat yang lebih baik.

\section{KESIMPULAN}

Hilah merupakan bentuk dari respon hukum Islam terhadap perkembangan kepentingan masyarakat, dalam menarik kemaslahatan yang dibutuhkan, dalam pemenuhan yang bersifat dharuri. 
Sebagai produk hukum, Hilah tidak boleh bertentangan dengan nilai-nilai universal hukum Islam. Hilah dipandang sebagai rumusan metodologi yang dijadikan sebagai salah satu dari metode Ijtihad yang mengedepankan kepentingan praktis dalam melestarikan lima unsur pokok yaitu menjaga agama, jiwa, keturunan, harta dan akal. Sehingga hilah bukan penyimpangan hukum, akan tetapi hilah dinilai sebagai makharij min al-mazaiq yaitu jalan keluar dari kesulitan.

Jadi hilah merupakan hal yang masih dibutuhkan. Hilah merupakan tindakan reaktif yaitu upaya mencari legitimasi hukum untuk melakukan hukum yang lebih ringan dengan pertimbangan maslahat, yang dilakukan untuk menyelesaikan (merespon) problematika masyarakat (menghindari dari perbuatan yang dilarang). Melakukan hilah itu boleh, selagi tidak membatalkan perkara haq atau tidak merusak tatanan syariat Allah yang lurus.

\section{Daftar Pustaka}

Abu Ishaq al-Syatibi. (1999) Al-Muwafaqat fi Ushul al-Syariah, Juz IV (Beirut: Dar alMa'rifah.

Aziz Dahlan. (1977). Ensiklopedi Hukum Islam Jilid III (Jakarta, PT. Ichtiar Baru Van Hoeve.

Chairuman pasaribu dan Suhrawardi K. Lubis . (1994). Hukum Perjanjian dalam Islam. Jakarta:Sinar Grafika.

Departemen Agama RI, Al-Qur'an dan Terjemahannya

Hendi Suhendi. (2010). Fiqh Mu'amalah. Jakarta: PT Raja Grafindo Persada.

Imam Abi Abdullah Muhammad bin Ismail bin Ibrahim bin Mughirah bin Bardzabah Bukhari Ju'fi. (1992). Shahih Bukhari . Beirut: Dar al Fikr.

M. Ali Hasan. (2003). Berbagai Macam Transaksi dalam Islam (Fiqh Muamalat). Jakarta: PT Raja Grafindo Persada.

M. Ali Hasan, Berbagai Macam Transaksi dalam Islam,

Majid al-Khadduri. (1999). Teologi Keadilan Perspektif Islam, terj (Surabaya, Risalah Gusti.

Mustafa Kamal, et. al. (2003) Fikih Islam. Yogyakarta: Citra Karsa Mandiri.

Saleh al-Fauzan (2005) Fikih Sehari-hari. Jakarta: Gema Inani Press.

Sayyid Sabiq (1988). Fiqih Sunnah, Juz 12 . Bandung: Al-Ma'arif.

Tim Penyusun, Kompilasi Hukum Ekonomi Syariah,

Wahbah al-Zuhaili. (2008) al-Fiqh al-Islami wa Adillatuhu, Juz IV,(Damaskus: Darul Fikr. 